\title{
Brush Control with Herbicides on Hill Pas- ture Sites in Southern Oregon
}

\author{
L.A. NORRIS, M.L. MONTGOMERY, L.E. WARREN, AND W.D. MOSHER
}

\section{Abstract}

Silvex alone or with 2,4-D in a $1: 1$ ratio at about 3 to $4 \mathrm{~kg} / \mathrm{ha}$ gave 60 to $100 \%$ control of many brush species including poison oak, Oregon oak, and maples. Picloram at $1 \mathrm{~kg} / \mathrm{ha}$ plus 2,4-D at 4 $\mathrm{kg} / \mathrm{ha}$ was most effective with respect to the amount of picloram; however, the mixture of $1 \mathrm{~kg} / \mathrm{ha}$ plus $2 \mathrm{~kg} / \mathrm{ha}$ respectively, was nearly as good. Complete pasture renovation in this area requires brush control, burning, fertilization, and seeding of desirable species. Picloram and 2,4-D disappear from soils in 29 months with no significant leaching into the soil profile at these study sites. Herbicide discharge in streamflow was small, representing $0.35 \%$ and $0.014 \%$ of applied picloram and $2,4-\mathrm{D}$. We believe that nearly all of the herbicide discharged from these watersheds represents residue deposited in dry stream channels or that mobilized by fall rains from adjacent streambanks. Significant overland movement of herbicides from upslope did not occur on these study areas. The probability of crop damage from irrigation with water from these watersheds is low.

Herbicides are valuable tools for vegetation management on pasture and rangelands. Southwestern Oregon has approximately 1 million acres which can be managed either as dry land pasture for cattle and sheep or as forest land for timber production. Much of this land has been converted from forest to pasture use. When seeded with desirable species and properly fertilized, areas like these can support 2.4 animal-unit-months per ha. However, invasion by a variety of brush species such as poison oak (Rhus diversiloba), wild rose (Rosa spp.), Ceanothus spp., blackberries (Rubus spp.), etc., can substantially reduce the carrying capacity of these sites. Effective and environmentally safe practices are needed to control woody species as part of the overall strategy for pasture improvement.

Murphy et al. (1975), Cannon (1974, 1977), Mosher et al. (1973), and others have shown the economic benefits of removing brush and properly managing accessible range sites. Many woody plants can be controlled adequately with phenoxy herbicides (Murphy et al. 1975; Cannon 1974, 1977). Other more resistant species such as poison oak, Oregon oak (Quercus kelloggii), wild rose, and blackberries are more effectively controlled with combinations of 4amino-3,5,6-trichloropicolinic acid (picloram) and 2,4-dichlorophenoxyacetic acid (2,4-D) (Gantz and Laning 1963, Hart 1966, Mosher et al. 1973). Rancher experience in the Douglas County, Oregon, area has shown that mechanized clearing or a combination of chemical control and fire can remove the brush. Seeding with perennial grasses such as perennial ryegrass (Lolium perenne) and inoculated subclover (Trifolium subterraneum) after treatment is important. These areas can produce 4,000 to 5,000

The authors are, respectively, chief research chemist, Pacific North west Forest and Range Experiment Station, U.S. Department of Agriculture, Forest Service, Corvallis, Oregon 97331 ; senior instructor, Department of Agricultural Chemistry, Oregon State University, Corvallis, Oregon 97331; field research development specialist, The Dow Chemical Company, Davis, California 95616; and Douglas County extension agent, Roseburg, Oregon 97470.

Authors acknowledge the substantial contribution of Berl Oar in installing and operating the stream flow and precipitation recording equipment, and (with Duane Moore) in collecting water and soil samples for chemical analysis.

Manuscript received March 10, 1980. $\mathrm{kg} / \mathrm{ha}$ of high quality legume-grass forage if properly fertilized (phosphorus and sulfur) and managed after these treatments have been applied.

Many of these hill-pasture sites in southwest Oregon are important sources of water for domestic and agricultural uses on nearby farms. Herbicide residues in stream water could adversely affect water quality. Picloram is a particularly active chemical which is more persistent and mobile in soil than many brush-control herbicides (Grover 1973, Norris 1970). Picloram has been found in some streams flowing from herbicide treated areas (Davis et al. 1968, Norris 1969, Bovey et al. 1974). 2,4-D is not as persistent nor mobile in soil as picloram; but under certain conditions, it may be washed from treated areas in measurable quantities (Barnett et al. 1967). The movement, persistence, and fate of these chemicals in soil and water are important in determining the likelihood that stream water quality will be adversely affected.

The objectives of this study were to (1) determine the effectiveness of several herbicides in controlling woody species as part of a dry land pasture improvement program, and (2) measure the movement, persistence, and fate of picloram and 2,4-D in soil and water after application of these herbicides to typical watersheds. 1

\section{Materials and Methods}

This study was conducted on two locations several kilometers a part. The Boyer Ranch study area, east of Roseburg, Oregon, had a 30-year history of burning every few years and normal grazing before this study. The soil series are Climax on the upper slopes and Dixonville on the lower. Both soils are heavy, dark clay soils which are slightly acid, have 3 to $4 \%$ organic matter content, and are derived from basic basalt. The Ronk Ranch study area, southwest of Roseburg, Oregon, is a forest site recently clea red and burned to make pasture. The soil is the Rink-Dement series (derived from sandstone) which is a reddish silt loam about $1 \mathrm{~m}$ deep and contains 3 to $4 \%$ organic matter. Average annual rainfall in the area is about $85 \mathrm{~cm}$.

\section{Herbicide Application and Vegetation Response}

The woody plants on the study sites are typical of the vegetation complex in northwestern California and western Oregon and Washington. The most prominent species are manzanitas (Arctotaphylos spp.), Ceanothus spp., Oregon oak, poison oak, wild rose, madrone (Arbutus menzesii), and blackberries. We determined the effectiveness of aerially applied mixtures of 2,4-D and picloram $\left(4: 1^{2}\right.$ and $2: 1^{3}$ ratios) and silvex $[2-(2,4,5-$

\footnotetext{
Mention of pesticides and proprietary products does not constitute an endorsement or recommendation for use by USDA nor does it imply registration under FIFRA as amended.

${ }^{2}$ TORDON ${ }^{\dagger} 101 \mathrm{l}$ Mixture Weed and Brush Killer contains $64.7 \mathrm{~g}$ picloram plus $240 \mathrm{~g}$ 2,4-D per liter as tri-isopropanol amine salts (product of The Dow Chemical Company).

TORDON 212 Mixture Herbicide contains $120 \mathrm{~g}$ picloram plus $240 \mathrm{~g} \mathrm{2,4-D}$ per liter as tri-isopropanol amine salts (product of The Dow Chemical Company)

${ }^{4}$ KURON@ Low-Volatile Brush and Weed Killer contains $480 \mathrm{~g}$ per liter of silvex as propylene gylcol butyl ether esters (product of The Dow Chemical Company).
} 


\begin{tabular}{|c|c|c|c|c|c|c|c|c|c|c|c|}
\hline \multirow[b]{3}{*}{ Treatment $^{1}$} & \multirow{3}{*}{$\begin{array}{c}\text { Rate of application } \\
\text { (kg/ha) }\end{array}$} & \multicolumn{8}{|c|}{ Percent brush control ${ }^{2}$} & & \\
\hline & & \multicolumn{2}{|c|}{ Poison oak } & \multicolumn{2}{|c|}{ Oregon oak } & \multicolumn{2}{|c|}{ Madrone } & \multicolumn{2}{|c|}{ Rose } & \multicolumn{2}{|c|}{ Cheatgrass growth } \\
\hline & & 1971 & 1972 & 1971 & 1972 & 1971 & 1972 & 1971 & 1972 & 1971 & 1972 \\
\hline Silvex & 3.4 & $82 c$ & 50 & $98 \mathrm{ab}$ & 50 & - & - & $100 \mathrm{a}$ & 98 & 150 & 175 \\
\hline Picloram + 2,4-D & $1.15+2.3$ & $93 a$ & 77 & $93 c$ & 84 & 100 & 95 & $100 a$ & 98 & 200 & 225 \\
\hline Picloram + 2,4-D & $2.3+4.6$ & $88 \mathbf{a b}$ & 90 & $99 a$ & 95 & 100 & 100 & $100 \mathrm{a}$ & 100 & 200 & 225 \\
\hline Picloram + 2,4-D & $1.2+4.6$ & $90 \mathrm{ab}$ & 91 & $95 \mathrm{bc}$ & 92 & 95 & 100 & $100 \mathrm{a}$ & 100 & 225 & 250 \\
\hline Untreated & $-\quad-$ & Od & 0 & Od & 0 & 0 & 0 & Od & 0 & 100 & 100 \\
\hline
\end{tabular}

Treated June 17, 1969.

${ }^{2}$ A verage control for 20 plants per treatment 26 months after treatment and one estimate for whole plot 38 months after treatment. Control rated on scale of 0 to 10 ( 0 is no control, 10 is dead top with no sprouts) and converted to percent based on untreated checks; the figures represent canopy reduction for that species. Figures in a given column with a lower case letter in common are not significantly different at the $95 \%$ probability level based on Duncan's new multiple range test.

${ }^{3}$ Grass growth is visual estimate of increased growth compared to untreated check.

trichlorophenoxy)propionic acid] alone or combined with 2,4-Ds at a $1: 1$ ratio on several woody species.

On the Boyer Ranch, adjacent 2- to 2.5-ha watersheds were treated with $3.4 \mathrm{~kg} / \mathrm{ha}$ silvex, $1.2 \mathrm{~kg} / \mathrm{ha}$ picloram plus $4.6 \mathrm{~kg} / \mathrm{ha}$ $2,4,-D^{2}$, or 1.15 or $2.3 \mathrm{~kg} / \mathrm{ha}$ picloram plus 2.3 or $4.6 \mathrm{~kg} / \mathrm{ha} 2,4-\mathrm{D}^{3}$. At the Ronk Ranch, adjacent watersheds about 2 ha in size were treated with $1.2 \mathrm{~kg} /$ ha picloram plus $4.6 \mathrm{~kg} / \mathrm{ha} 2,4-\mathrm{D}$ or $3.4 \mathrm{~kg} / \mathrm{ha}$ each of silvex plus 2,4-D. Treatments were applied in early June by helicopter as thin invert emulsions ( $93.5 \mathrm{liter} / \mathrm{ha}$ ) with an oil:water ratio of 1:3 (1\% LTA-14 inverting agent). Rainy weather prevailed for 3 days prior to the application, and fog and mist persisted on the 2 days of application. The maximum temperature during application was $17^{\circ} \mathrm{C}$.

Herbicide effectiveness on woody plants was estimated 26 and 38 months after treatment by rating on a scale of 0 to 10 ( 0 denoting no effect, and 10 denoting complete plant kill with no resprouting). Response of 20 plants on random transects in each plot area was estimated and subjected to analysis of variance with a Duncan's multiple range test of specific differences. The average rating for each treatment was converted to percent control for each species based on the untreated check. The rating system accounts for top-growth reduction which reflects canopy reduction. On the Ronk Ranch, the area was burned 16 months after herbicide application, fertilized, and planted to inoculated subclover and perennial ryegrass. The volume of grass growth at the rating periods 26 and 38 months after treatment was estimated visually compared to adjacent untreated areas. About 21 months after spraying, $1002-0^{6}$ Douglas fir (Pseudotsuga menziesii) seedlings were planted in the plots treated with picloram to assess the residual effects of this herbicide on transplanted conifers.

\section{Herbicide Residues}

We determined the behavior of 2,4-D and picloram on the Boyer Ranch by treating a 7-ha watershed with $2.3 \mathrm{~kg} /$ ha picloram and $4.6 \mathrm{~kg} / \mathrm{ha} 2,4-\mathrm{D}$. Spray distribution and deposit was evaluated using 10.2- $\times 12.7-\mathrm{cm}$ Mylar cards on $15-\times 15 \mathrm{~cm}$-aluminum plates. The plates were above the brush (about $2 \mathrm{~m}$ above the ground) on posts. Cards were located on three transects across the upper ( 22 cards), middle ( 22 cards), and lower (10 cards) parts of the watershed. A cluster of four cards in a $0.4-\mathrm{m}^{2}$ a rea near the center of each transect was also used to evaluate deposit variability.

A $90^{\circ} \mathrm{V}$-notch weir and water-level monitoring station were installed in the channel of the intermittent stream at the bottom of the watershed (site 1). A 46-cm-diameter culvert placed upright in the streambank served as a stilling well and was connected to the pond behind the weir through a small pipe. A FW-1 stream-level recorder was installed on top of the stilling well, and a recording rain gage was nearby. Water from site 1 flows into a larger stream which was sampled at site 2, approximately $400 \mathrm{~m}$ downstream

${ }^{5}$ ESTERON 998 Concentrate Low Volatile Herbicide contains $480 \mathrm{~g}$ per liter of 2,4-D as the propylene glycol butyl ether ester (product of The Dow Chemical Company).

'Conifer seedlings 2 years in nursery seedbed (2-) and none (-0) in secondary plant bed before outplanting. from the weir. Water passing site 2 flows into a larger stream sampled at site 3 , which is $1,500 \mathrm{~m}$ downstream from the weir. Site 3 is at a U.S. Geological Survey stream-level recording station. Precipitation record and sampling dates are in Table 5.

Water sa mples were stabilized with sodium hydroxide (to $\mathrm{pH} 12$ ) until analyzed for herbicide residues. Soil samples were collected from three different soil pits on each transect at each sampling time and frozen until analyzed. Samples of the soil profile, in $15-\mathrm{cm}$ segments, were taken from a clean face of the pit to eliminate contamination with surface residues. Tools were carefully cleaned between each collection.

A much more limited herbicide residue study was conducted on the Ronk Ranch. A 5-ha watershed was treated with $1.68 \mathrm{~kg} / \mathrm{ha}$ picloram and $6.72 \mathrm{~kg} / \mathrm{ha} 2,4-\mathrm{D}$. Water sampling site 1 was a small spring in the middle of the treated area, while site 2 was a depression at the base of the slope where water collected before it was discharged through a culvert onto a relatively flat pasture.

\section{Herbicide Residue Analysis}

Herbicide residues were extracted, purified, and measured using the procedures described by Norris (1970) and Norris et al. (1977). In general, water samples were acidified, extracted with ether, and the ether extracts methylated with diazomethane before microcoulometric gas chromatography. Herbicide residues in soil were extracted with sodium hydroxide, and after acidification were extracted with ether. The ether extract was purified using a Woelm basic alumina column and, after methylation, the residues measured by microcoulometric gas chromatography. Analytical results were corrected for recovery (water: $83 \pm 4 \%$ picloram, $94 \pm$ 4\% 2,4-D; soil: $74 \pm 5 \%$ picloram, $80 \pm 5 \%$ 2,4-D).

\section{Results}

\section{Vegetation Response}

All treatments gave effective woody plant control for 2 years on the Boyer Ranch (Table 1). However, the following year poison oak and Oregon oak began to sprout in the plot treated with silvex and to some extent in the plot treated with $2.3 \mathrm{~kg} / \mathrm{ha} 2,4-\mathrm{D}$ plus $1.15 \mathrm{~kg} / \mathrm{ha}$ picloram. Control of these species with $4.6 \mathrm{~kg} / \mathrm{ha}$ 2,4-D plus $1.2 \mathrm{~kg} /$ ha picloram or $4.6 \mathrm{~kg} / \mathrm{ha} 2,4-\mathrm{D}$ plus $2.3 \mathrm{~kg} / \mathrm{ha}$ picloram persisted into the third year. The brush control with all treatments allowed good recovery of the annual grasses present, mainly cheatgrass (Bromus tectorum). The improvement in grass growth persisted and allowed a considerable increase in carrying capacity.

On the Ronk Ranch, the combination of herbicides plus fire provided excellent overall control of woody plants (Table 2). Most conifers, maples, and oaks, some as tall as 10 to $15 \mathrm{~m}$, were killed by $4.6 \mathrm{~kg} / \mathrm{ha} 2,4-\mathrm{D}$ plus $1.2 \mathrm{~kg} / \mathrm{ha}$ picloram. At the time of treatment, other species present included blackberries and black raspberries, thimbleberry (Rubus parviflorus), blueblossom (Ceanothus thyrsiflorus), snowbrush (Ceanothus velutinus), willow (Salix spp.), black poplar (Populus balsamifera), madrone, and huckleberry (Vaccinium sp.). These plants were essentially all eliminated by this treatment. Silvex plus 2,4-D did not provide as complete control of 
Table 2. Control of woody plants on Ronk Ranch study area.

\begin{tabular}{|c|c|c|c|c|c|c|}
\hline \multirow[b]{2}{*}{ Treatment ${ }^{\prime}$} & \multirow{2}{*}{$\begin{array}{l}\text { Rate of } \\
\text { application } \\
\text { (kg/ha) }\end{array}$} & \multicolumn{4}{|c|}{$\begin{array}{l}\text { Percent brush control }{ }^{2} \\
\text { after } 38 \text { months }\end{array}$} & \multirow[b]{2}{*}{$\begin{array}{l}\text { Ryegrass } \\
\text { growth }\end{array}$} \\
\hline & & $\begin{array}{l}\text { Doug- } \\
\text { las fir }\end{array}$ & Maples $^{3}$ & $\begin{array}{c}\text { Poison } \\
\text { oak }\end{array}$ & $\begin{array}{l}\text { Oregon } \\
\text { oak }\end{array}$ & \\
\hline $\begin{array}{l}\text { Silvex }+ \\
\text { 2,4-D } \\
\text { Picloram }+\end{array}$ & $3.4+3.4$ & 95 & 45 & 60 & - & 200 \\
\hline $\begin{array}{l}\text { 2,4-D } \\
\text { Picloram + }\end{array}$ & $1.2+4.6$ & 97 & 75 & 85 & 70 & 200 \\
\hline $\begin{array}{l}2,4-D \\
\text { Untreated }\end{array}$ & $\begin{array}{c}1.68+6.72 \\
-\end{array}$ & $\begin{array}{r}98 \\
0\end{array}$ & $\begin{array}{r}90 \\
0\end{array}$ & $\begin{array}{r}93 \\
0\end{array}$ & $\begin{array}{r}90 \\
0\end{array}$ & $\begin{array}{l}300 \\
100\end{array}$ \\
\hline
\end{tabular}

ITreated June 17, 1969.

${ }_{2}^{2}$ Average percent control of each species for the respective treatment by visual inspection 38 months after application. Control rated on basis of 0 to 10 ( 0 is no control, 10 is dead top with no sprouts) and converted to percent based on untreated checks.

${ }^{3}$ Includes vine maple (Acer circinatum) and bigleaf maple (Acer macrophyllum) with stems up to $25 \mathrm{~cm}$ in diameter and $15 \mathrm{~m}$ tall.

"Grass growth is visual estimate of percent improvement over untreated check.

the larger trees and sprouting species as the mixtures containing picloram. The overall brush reduction was greater than indicated by the figures for degree of control in Table 2 because of the nearly complete kill of other brush species. Grass recovery was excellent.

Douglas-fir seedlings (2-0 stock) were planted 21 months after application of $1.2 \mathrm{~kg} /$ ha picloram and $4.6 \mathrm{~kg} / \mathrm{ha} 2,4-\mathrm{D}$. They showed no visual symptoms of toxicity from residues of picloram 5 months after planting ( 26 months after application of herbicide). Perennial ryegrass and subclover were well established in all plots 3 years after spraying.

\section{Herbicide Residues \\ Herbicide Deposit}

Most of the application was made at the Boyer Ranch while the helicopter was traveling downhill, perpendicular to the spray interception card transects. At least one flight was made across the top of the watershed and included the upper line of cards. Spray deposition averaged $3.5 \mathrm{~kg} / \mathrm{ha} 2,4-\mathrm{D}$ and $2.4 \mathrm{~kg} / \mathrm{ha}$ picloram; but it was highly variable among spray interception stations, even on the four cards clustered within a $0.4 \mathrm{~m}^{2}$ area (Table 3 ).

The coefficients of variation are substantially smaller for data from the four clusters, but a Bartlett's test (Netter and Wasserman 1974) showed no significant difference between the variances for clusters and lines for 2,4-D. For picloram, the difference was significant $(P<0.05)$, but the magnitude of the actual difference was not large. These data illustrate the difficulty of trying to estimate herbicide deposition accurately based on sampling with spray cards. A large number of samples are needed to assess spray deposit. Based on data from only the upper line, 65 spray cards would have been needed to estimate spray deposit within $10 \%$ of the population mean at the $95 \%$ probability level. Using data points from all parts of this watershed, 195 samples would be required to obtain this same level of accuracy.

\section{Herbicide Residues in Soil}

Herbicide residues in soil were studied only on the Boyer Ranch study area. No soil samples were collected immediately after application. We calculated the initial concentrations of herbicide in the surface 0 - to $15-\mathrm{cm}$ layer of soil were $0.8 \mathrm{ppm} 2,4-\mathrm{D}$ and $0.4 \mathrm{ppm}$ picloram, based on the intended rate of application and a $60 \%$ interception of spray material by overstory vegetation (Altom and Stritzke 1972). Based on these assumptions, the residues of 2,4-D and picloram measured in the 0 - to $15-\mathrm{cm}$ layer of soil after 10 months reflect a $98 \%$ and $85 \%$ loss, respectively, of the initial soil residue level (Table 4). If first order kinetics apply, the half-life was 54 days for 2,4-D and 112 days for picloram during this period. These values are within the estimates for picloram reported by
Table 3. Spray deposit' ${ }^{1}$ based on analysis of herbicide on $10.2-\times 12.7-\mathrm{cm}$ Mylar spray interception cards.

\begin{tabular}{|c|c|c|c|c|c|c|}
\hline \multirow[b]{2}{*}{ Position on slope } & \multicolumn{3}{|c|}{ Transect $^{2}$} & \multicolumn{3}{|c|}{ Four-card cluster ${ }^{3}$} \\
\hline & $\overline{\mathbf{X}}$ & $\mathbf{S}$ & $\mathrm{C}$ & $\overline{\mathbf{X}}$ & $\mathbf{S}$ & C \\
\hline & \multicolumn{2}{|c|}{$\mathrm{kg} / \mathrm{ha}$} & Percent & \multicolumn{2}{|c|}{$\mathrm{kg} / \mathrm{ha}$} & Percent \\
\hline $\begin{array}{l}\text { Lower } \\
\text { 2,4-D } \\
\text { Picloram }\end{array}$ & $\begin{array}{l}2.50 \\
1.87\end{array}$ & $\begin{array}{l}1.03 \\
0.74\end{array}$ & $\begin{array}{l}41 \\
40\end{array}$ & $\begin{array}{l}2.79 \\
1.83\end{array}$ & $\begin{array}{l}0.69 \\
0.46\end{array}$ & $\begin{array}{l}25 \\
25\end{array}$ \\
\hline $\begin{array}{l}\text { Middle } \\
\text { 2,4-D } \\
\text { Picloram }\end{array}$ & $\begin{array}{l}1.76 \\
1.28\end{array}$ & $\begin{array}{l}0.97 \\
0.67\end{array}$ & $\begin{array}{l}55 \\
52\end{array}$ & $\begin{array}{l}2.11 \\
1.48\end{array}$ & $\begin{array}{l}0.17 \\
0.09\end{array}$ & $\begin{array}{l}8 \\
6\end{array}$ \\
\hline $\begin{array}{l}\text { Upper } \\
\text { 2,4-D } \\
\text { Picloram }\end{array}$ & $\begin{array}{l}5.69 \\
3.83\end{array}$ & $\begin{array}{l}2.20 \\
1.37\end{array}$ & $\begin{array}{l}39 \\
36\end{array}$ & $\begin{array}{l}5.84 \\
3.07\end{array}$ & $\begin{array}{l}0.56 \\
0.45\end{array}$ & $\begin{array}{l}10 \\
15\end{array}$ \\
\hline $\begin{array}{l}\text { Mean }^{4} \\
\text { 2,4-D } \\
\text { Picloram }\end{array}$ & $\begin{array}{l}3.50 \\
2.43\end{array}$ & $\begin{array}{l}2.43 \\
1.56\end{array}$ & $\begin{array}{l}69 \\
64\end{array}$ & $\begin{array}{l}3.58 \\
2.13\end{array}$ & $\begin{array}{l}1.76 \\
0.79\end{array}$ & $\begin{array}{l}49 \\
37\end{array}$ \\
\hline
\end{tabular}

I Mean $\overline{\mathbf{X}}$ ), standard deviation (S), coefficient of variation (C).

2Data for each of three transects across watershed. Lower line 10 cards, middle line 22 cards, upper line, 22 cards.

${ }^{3}$ Cluster of four cards in a $0.4 \mathrm{~m}^{2}$ a rea near the center of the transect.

4Mean values for all lines or clusters.

Hamaker et al. (1968) and Grover (1967) but substantially larger for 2,4-D than usually reported (Altom and Stritzke 1972, Plumb et al. 1977). Between 10 and 18 months after application, picloram and 2,4-D residues disappeared from the $0-$ to $15-\mathrm{cm}$ depth of soil at rates equivalent to half-lives of 150 and 300 days. These long half-lives reflect the declining rate of herbicide degradation which commonly occurs as residue levels approach zero. We believe both 2,4-D and picloram would have exhibited shorter half-lives if our sampling had been concentrated in the first 60 days after application. Mixed order kinetics are expected in long term studics of the disappearance of 2,4-D and picloram from soil (Norris 1970).

There was no evidence of 2,4-D leaching below $15 \mathrm{~cm}$ in the soil. Maximum picloram penetration was $45 \mathrm{~cm}$ at 10 months in this heavy, clay soil. No picloram residues were detected below $15 \mathrm{~cm}$, more than 10 months after application. These results are in general agreement with other studies of herbicide mobility in soil. Piclora $m$ is considered mobile in soil; but in nearly all field studies, most of the herbicide is in the top $15 \mathrm{~cm}$ of soil and the concentration decreases sharply with depth in the soil profile (Merkle et al. 1966, Baur et al. 1972).

\section{Herbicide Residues in Water}

Boyer Ranch. The results of analysis of stream water for herbicide residues at the Boyer Ranch are in Table 5. Precipitation, stream discharge, and herbicide discharge data for site 1 are in Figure 1.

Table 4. Average herbicide residues (ppmw) in soil from Boyer Ranch study area after aerial application of $2.3 \mathrm{~kg}$ picloram and $4.6 \mathrm{~kg}$ 2,4-D per hectar. ${ }^{1}$

\begin{tabular}{lllll}
\hline \multirow{2}{*}{$\begin{array}{l}\text { Depth in soil } \\
\text { (cm) }\end{array}$} & Herbicide & 10 & \multicolumn{3}{c}{ Months after application } \\
\cline { 3 - 5 } $0-15$ & 2,4-D & 0.017 & 0.010 & 29 \\
\hline \multirow{2}{*}{$15-30$} & Picloram & 0.064 & 0.022 & 0.001 \\
& 2,4-D & 0 & 0 & 0 \\
$30-45$ & Picloram & 0.005 & 0 & 0 \\
& 2,4-D & 0 & 0 & 0 \\
$45-60$ & Picloram & 0.001 & 0 & 0 \\
& 2,4-D & 0 & 0 & 0 \\
& Picloram & 0 & 0 & 0 \\
\hline
\end{tabular}

IAverage of nine plots, three on each of three transects.

20 means less than 0.001 ppmw. 


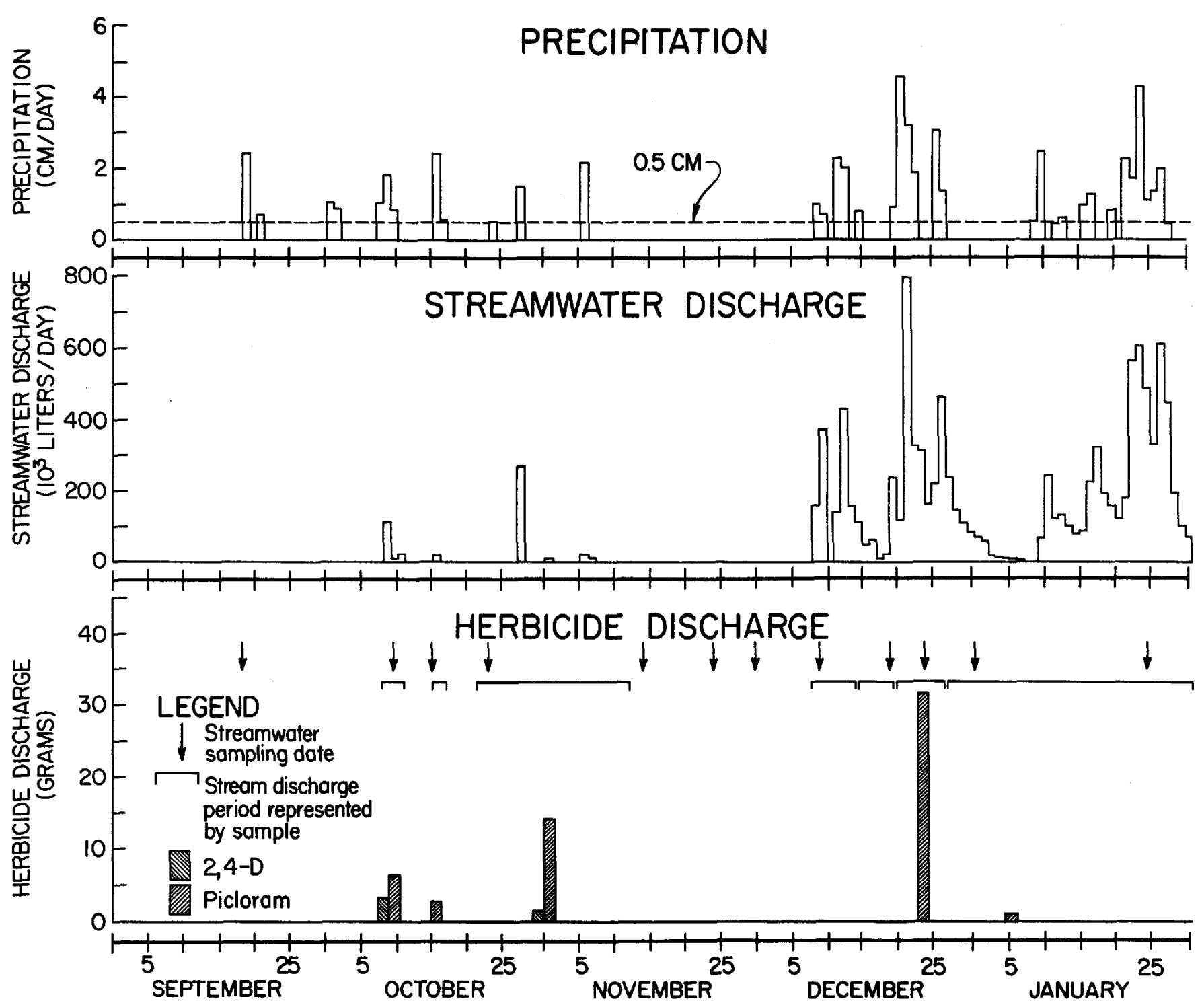

Fig. 1. Daily precipitation exceeding $0.5 \mathrm{~cm}$ in 24 hours, stream discharge, and herbicide discharge at the weir (site 1 ) on a hill-pasture after aerial application of $2.3 \mathrm{~kg} / \mathrm{ha}$ picloram and $4.6 \mathrm{~kg} / \mathrm{ha} \mathrm{2.4-D.} \mathrm{Streamwater} \mathrm{discharge} \mathrm{between} \mathrm{December} 21$ and January 1 were estimated using a linear regression relating discharge at site I to discharge at site 3.

The stream sampled at site 1 was dry at the time of herbicide application in June and remained so until the first significant rainfall on September 18. This rain formed some puddles in the stream channel but no runoff into the basin behind the weir. $A$ water sample collected in a small puddle about $5 \mathrm{~m}$ upstream from the weir contained $0.11 \mathrm{ppm}$ picloram, but no 2,4-D. Rain beginning on October 7 filled the weir basin, and the first flow of water over the weir occurred on October 8 . Relatively little water flowed from the watershed between October 9 and October 27, when an intense storm occurred. No samples were collected during the October 27 storm. There was no significant precipitation between November 6 and a period of intense storm activity beginning December 8 . There was continuous stream discharge for the next 4 months. The last water sample with a detectable residue of 2,4-D was taken from the weir basin on October 21 . Picloram residues were detected only twice between October 21 and January 1. No herbicide was detected in any water sample collected at site 1 over the next 1.5 years.

The concentration of herbicide we detected is considerably lower than those reported in several other studies (Bovey and Scifres 1971, Davis et al. 1968, Trichell et al. 1968). In those studies, however, streamflow occurred within 10 days of application, com-

pared to 3.5 months in this study.

The discharge of herbicide from the watershed was calculated from water discharge and the average herbicide concentration for the period represented by a water sample (Fig. 1). An equipment malfunction resulted in loss of streamwater discharge data from December 21 through January 1. We developed a linear regression to estimate streamwater discharge at site 1 based on discharge at site 3 during this period. The discharge measured at site 3 . accounted for $83 \%$ of the variation in discharge at site 1 calculated using the regression equation.

Approximately $0.014 \%$ (4.5 grams) of the $2,4-\mathrm{D}$ and $0.35 \%$ ( 57.14 grams) of the picloram applied to the watershed were discharged in stream water in the 7 months between the time of application and the time the last sample containing herbicide was collected. Herbicide discharge occurred during each streamflowgenerating storm in October and early November. After the 4-week dry period in November and early December, no herbicide discharge was detected during two storms until a particularly intense storm occurred around December 20. This storm, which washed out the dam, caused what we estimate to be the largest outflow of picloram (no 2,4-D) during the study. No herbicide discharge was detected after January 1. 
Based on its length and width, the dry stream channel occupies $0.2 \%$ of the total area of the watershed. We believe most of the herbicide discharged from the watershed represents material which was mobilized during periods of heavy precipitation from the channel and banks of the intermittent stream. The rapid dissipation of herbicide in the soil and insignificant leaching in the profile were probably important factors in minimizing stream contamination.

Water samples collected at site 2 did not show significant residues of herbicide except for October 21 , when a single sample containing $0.007 \mathrm{ppm}$ picloram was collected (Table 5). At site 3, only three samples contained detectable herbicide. The lack of residues in samples collected on the same dates at sites 1 and 2 suggests the picloram in the samples from site 3 were not coming from the treated watershed. Strea mwater sampling continued at all three sites for 2 years after the application with no further residues detected.

Ronk Ranch. Herbicide residue data for water samples collected at sites 1 and 2 at the Ronk Ranch are in Table 6 . Site 1 was only damp, and site 2 was dry between the time of application and the first significant rain in September. Maximum residue levels were lower than at the Boyer Ranch, but averages were higher and persisted for a longer period of time.

The last samples which contained detectable herbicide residues were taken on December 18 . The first storm of sufficient intensity and duration to result in the movement of water from the watershed towards a nearby perennial stream occurred on December 21 , but the water samples at site 2 did not contain detectable residues at that time. Water samples were collected periodically at sites 1 and 2 for the next 20 months, but no further residues were detected.

Residues in samples collected at site 1 probably represent herbicide deposition on the ground immediately adjacent to the spring and their subsequent movement over the surface during precipitation, rather than ground water pollution. The general synchrony of residues with storm events and the lack of long-term, low level outflow at site 1 supports this hypothesis. Residues in water samples collected at site 2 were probably mobilized in the stream channels and banks between sites 1 and 2 . Water movement over compacted animal trails was observed during storm periods and probably also contributed to the residues detected at site 2 .

Table 5. Herbicide residues (ppmw) in streamwater from Boyer Ranch study area after aerial application of $2.3 \mathrm{~kg}$ picloram and $4.6 \mathrm{~kg} 2,4-\mathrm{D}$ per hectare in June.

\begin{tabular}{|c|c|c|c|c|c|c|c|}
\hline \multirow{3}{*}{$\begin{array}{l}\text { Samp- } \\
\text { ling date } \\
\text { (month- } \\
\text { day) }\end{array}$} & \multirow{3}{*}{$\begin{array}{c}\text { Precipita } \\
\text { ation }^{2} \\
(\mathrm{~cm})\end{array}$} & \multicolumn{6}{|c|}{ Stream sampling site ${ }^{1}$} \\
\hline & & \multicolumn{2}{|r|}{1} & \multicolumn{2}{|r|}{2} & \multicolumn{2}{|r|}{3} \\
\hline & & 2,4-D & Picloram & 2,4-D & Picloram & 2,4-D & Picloram \\
\hline $9-18$ & 2.5 & $0^{3}$ & 0.110 & 0.001 & 0 & 0.001 & $\mathbf{0}$ \\
\hline $10-9$ & 7.9 & 0.022 & 0.043 & 0.001 & 0 & 0.001 & 0 \\
\hline $10-13$ & 0 & 0 & 0.064 & 0 & $\mathbf{0}$ & 0 & 0 \\
\hline $10-21$ & 3.0 & 0.003 & 0.039 & 0 & 0.007 & 0 & 0 \\
\hline $11-14$ & 5.0 & 0 & 0 & 0 & 0 & 0 & $\mathbf{0}$ \\
\hline $11-24$ & 0 & 0 & 0 & 0 & $\mathbf{0}$ & 0 & 0 \\
\hline $12-1$ & 0.1 & 0 & 0 & $\mathbf{0}$ & $\mathbf{0}$ & $\mathbf{0}$ & 0 \\
\hline $12-9$ & 2.0 & 0 & 0 & 0 & 0 & 0 & 0.001 \\
\hline $12-19$ & 6.8 & 0 & 0 & 0 & $\mathbf{0}$ & 0 & 0.003 \\
\hline $12-24$ & 9.9 & 0 & 0.012 & 0 & 0 & 0 & 0 \\
\hline $1-1$ & 4.6 & 0 & 0.001 & 0 & 0 & 0 & 0 \\
\hline $1-244$ & 18.6 & 0 & 0 & 0 & 0 & 0 & 0.001 \\
\hline
\end{tabular}

1Site 1 is at base of the watershed. Site 2 is $\mathbf{4 0 0}$ meters from site 1 on a stream which receives water from the watershed. Site 3 is approximately $1,500 \mathrm{~m}$ from the watershed and receives water from both sites $I$ and 2 .

${ }^{2}$ Cumulative precipitation between sampling dates.

30 means less than 0.001 ppmw

4Last date when detectable levels of herbicide occurred. Water sampling continued for the aext 1.5 years.
Table 6. Herbicide residues (ppmw) in water from Ronk Ranch study area after application of $1.6 \mathrm{~kg}$ picloram and $6.8 \mathrm{~kg} 2,4-\mathrm{D}$ in June.

\begin{tabular}{|c|c|c|c|c|c|}
\hline \multirow{3}{*}{$\begin{array}{l}\text { Sampling } \\
\text { date } \\
\text { (month-day) }\end{array}$} & \multirow{3}{*}{$\begin{array}{l}\text { Precipita- } \\
\text { ation }^{2} \\
(\mathrm{~cm})\end{array}$} & \multicolumn{4}{|c|}{ Water sampling site } \\
\hline & & \multicolumn{2}{|r|}{1} & \multicolumn{2}{|r|}{2} \\
\hline & & 2,4-D & Picloram & $\overline{2,4-D}$ & Picloram \\
\hline $9-18$ & 2.5 & 0.005 & 0.007 & 0.010 & 0.057 \\
\hline $10-10$ & 7.9 & 0.002 & 0.035 & 0.007 & 0.071 \\
\hline $10-15$ & 2.4 & $0^{3}$ & 0.016 & 0.003 & 0.049 \\
\hline $10-24$ & 1.2 & 0 & 0.001 & 0 & 0.007 \\
\hline $10-30$ & 1.6 & 0 & 0 & 0 & 0.006 \\
\hline $11-5$ & 2.8 & 0 & 0.003 & 0 & 0.019 \\
\hline $11-13$ & 0.4 & 0 & 0 & 0 & 0.010 \\
\hline $11-17$ & 0 & 0 & 0.001 & 0 & 0.010 \\
\hline $11-23$ & 0.2 & 0 & 0 & 0 & 0.004 \\
\hline $11-30$ & 0.1 & 0 & 0 & 0 & 0.002 \\
\hline $12-8$ & 0.5 & 0 & 0 & 0.001 & 0.003 \\
\hline $12-11$ & 2.0 & 0 & 0 & 0 & 0.026 \\
\hline $12-18^{4}$ & 2.9 & 0 & 0.001 & 0 & 0.002 \\
\hline $12-21$ & 7.62 & 0 & 0 & 0 & 0 \\
\hline $12-30$ & 8.13 & 0 & 0 & 0 & 0 \\
\hline
\end{tabular}

ISite 1 is a small spring in the treated area. Site 2 is a small pool at the bottom of the watershed.

${ }^{2}$ Cumulative precipitation between sampling dates

30 means less than 0.001 ppmw.

'Last date when detectable levels of herbicide occurred. No residues detected in samples collected over next 1.5 years.

\section{Discussion}

\section{Brush Control and Pasture Rehabilitation}

Although control of brush was good with all treatments, it was best with $1.2 \mathrm{~kg} /$ ha picloram plus $4.6 \mathrm{~kg} / \mathrm{ha} 2,4-\mathrm{D}$. The $1: 4$ ratio of picloram to $2,4-\mathrm{D}$ in this mixture seems better from an economic standpoint than the 1:2 ratio. The use of fire to help remove much of the woody top growth adds to the impact of the herbicide, reduces residues of picloram in the soil, and provides a good seedbed in which to plant desirable grass seed. Treated areas should not be burned for at least 3 months after spraying to maximize drying for a good burn.

All herbicide applications were effective in controlling the brushy species that dominated both the Boyer and Ronk Ranch study areas. Pasture rehabilitation included burning the year after herbicide application, then aerial application of $224 \mathrm{~kg} / \mathrm{ha} 0-40-0$ $20 S$ fertilizer and later seeding with $22.4 \mathrm{~kg} / \mathrm{ha}$ inoculated subterranean clover. Once established with a proper fertilization program, subterranean clover competed well with most of the brush species. Grazing by sheep, goats, or cattle inhibited brush regeneration effectively. If adequate stocking rates of clover are achieved and grazing intensity is controlled, poison oak, wild rose, madrone, black oak, and white oak will be eliminated from similar pastures in this area.

Studies of pature improvement in this area indicate effective brush control with successful establishment of subclover will increase forage (Cannon 1977, Mosher et al. 1973). Yields in these trials went from less than $1,100 \mathrm{~kg}$ / ha dry matter before treatment to between 4,400 and $5,500 \mathrm{~kg} /$ ha after treatment. The mid summer quality of the feed improved from 3 to $4 \%$ protein before to 6 to $10 \%$ after treatment. Prior to pasture rehabilitation, the area supported 20 to 30 goats and sheep for part of the year. Currently, the same area is able to carry 150 sheep and 15 to 20 cattle for several months of the year.?

\section{Herbicide Residues}

The amount of herbicide discharged from the Boyer Ranch watershed was small and can be accounted for by mobilization of residues in or near the stream channel. Picloram is often cited as a

'Based on data from clipped plots, observations of W.D. Mosher, and local rancher experience. 
persistent mobile chemical, but in this environment neither its persistence nor mobility were sufficient to contribute residues greater than $0.1 \mathrm{mg}$ / liter from upslope sites to the stream. The lack of measurable residues in samples collected more than 7 months after application substantiates this conclusion.

Evans and Duseja (1975), Bovey et al. (1974), and Davis and Ingebo (1973) all reported substantial residues of picloram in runoff water collected close to treated areas soon after heavy precipitation. In most cases, however, residues were low or not detected more than 3 months after application. In each case, herbicide resid ues appeared to have been mobilized during precipitation and, after several such events, residue levels decreased. Our results follow a similar pattern except the residues we found were lower but were detected for a longer period after application. Of course, there was essentially no rainfall the first 3 months after application at our study sites, so residues were available for decomposition for a longer period than in the experiments cited above.

The concentration of 2,4-D we found in run off water at both the Boyer and Ronk Ranches would not cause injury in either sprinkler- or furrow-irrigated soybeans or sugar beets (Bruns et al. 1973). The concentration of picloram detected in samples collected through December $24(0.012$ to $0.110 \mathrm{mg} /$ liter) would injure sensitive crops (Bovey and Scifres 1971). Irrigation would not normally be practiced at that time of year, however, so the probability of crop injury is small. Dilution and adsorption with downstream movement will reduce the concentration of herbicides in the water, further minimizing the risk of crop damage. Where stream water for irrigation may be taken close to areas scheduled for treatment with picloram (or 2,4-D), buffer zones of untreated land should be left on either side of stream channels to minimize the entry of herbicide to the water. The residue levels of picloram and 2,4-D which occurred in stream water actually discharged from the watershed did not exceed levels suggested as safe (less than 0.035 $\mathrm{mg} /$ liter) for aquatic animal species (Wood ward 1979, Newton and Norgren 1977).

The increased carrying capacity achieved in this program and the negligible adverse environmental effects should make such hill pasture rehabilitation attractive to land owners in this area.

\section{Literature Cited}

Altom, J.D., and J.F. Stritzke. 1972. Persistence of brush control herbicides in a blackjack and postoak soil. Proc. South. Weed Sci. Soc. 20:302. Barnett, A.P., E.W. Hauser, A.W. White, and J.H. Holkday. 1967. Loss of 2,4-D in washoff from cultivated and fallow land. Weeds 15:133-137.

Baur, J.R., R.D. Baker, R.W. Bovey, and J.D. Smith. 1972. Concentration of picloram in the soil profile. Weed Sci. 20:305-309.

Bovey, R.W. and C.J. Scifres. 1971. Residual characteristics of picloram in grassland ecosystem. Texas Agr. Exp. Sta. Bull. B-1111 College Sta. 24 p.

Bovey, R.W., E. Burnett, C. Richardson, M.G. Merkle, J.R. Baur, W.G. Knisel. 1974. Occurrence of 2,4,5-T and picloram in surface runoff water in the blacklands of Texas. J. Environ. Qual. 3:61-64.
Bruns, V.F., B.L. Carlile, and A.D. Kelly. 1973. Responses and residues in sugarbeets, soybeans, and corn irrigated with 2,4-D or silvex treated water. Agr. Res. Ser. U.S. Dep. Agr. Tech. Bull. 1476. U.S. Gov. Print. Offic. Washington, D.C. $31 \mathrm{p}$.

Cannon, L. 1974. Clearing brush on Coos County, Oregon hill pastures with silvex. Down to Earth 30:(3): 17-18.

Cannon, L. 1977. Brush clearing on southwestern Oregon hill pastures with silvex. Down to Earth 33(1):20.

Davis, E.A. and P.A. Ingebo. 1973. Picloram movement from a chaparral watershed. Water Resour. Res. 9:1304-1313.

Davis, E.A., P.A. Ingebo, and C.P. Pase. 1968. Effect of a watershed treatment with picloram on water quality. U.S. Dep. Agr. Forest Scrv. Rocky Mt. Forest and Range Exp. Sta. Res. Note RM-100. Fort Collins, Co. 4 p.

Evans, J.O. and D.R. Duseja. 1975. Herbicide contamination of surface runoff waters. U.S. Environ. Prot. Agency. Washington, D.C., Environ. Prot. Tech. Ser. EPA-R2-73-266. 99 p.

Gantz, R.L. and E.R. Laning. 1963. Tord on for the control of woody rangeland species in the western United States. Down to Earth 19(3):1013.

Grover, R. 1967. Studies on the degradation of 4-amino-3,5,6trichloropicolinic acid in soil. Weed Res. 7:61-67.

Grover, R. 1973. Movement of picloram in soil columns. Can. J. Soil Sci. 53:307-314.

Hamaker, J.W., C.R. Youngson, and C.A.I. Goring. 1968. Rate of detoxification of 4-amino-3,5,6-trichloropicolinic acid in soil. Weed Res. 8:4657.

Hart, G.L. 1966. Control of poison oak on military reservations with Tordon. Down to Earth 22(3):6-7.

Merkle, M.G., R.W. Bovey, and R. Hall. 1966. The determination of picloram residues in soil using gas chromatography. Weeds 14:161-164.

Mosher, W., H. Hatfield, and W. Krueger. 1973. Minimum seedbed preparation for seeding native grass hills in western Oregon. Abstract of Papers. 26th Annual Mtg., Soc. Range Manage. p. 7-8.

Murphy, A.H., O.A. Leonard, and D.T. Torell. 1975. Chaparral shrub control as influenced by grazing, herbicides, and fire. Down to Earth $31(3): 1-8$.

Netter, John and William Wasserman. 1974. Applied linear statistical models. Richard D. Irwin Inc. Homewood, 111. 842 p.

Newton, M. and J.A. Norgren. 1977. Silvicultural chemicals and protection of water quality. U.S. Environ. Prot. Agency. Seattle, Wa. EPA 910/977-036. 224 p.

Norris, L.A. 1969. Herbicide runoff from forest lands sprayed in summer. In: Res. Progress Rep., West. Soc. of Weed Sci. p. 24-26.

Norris, L.A. 1970. Degradation of herbicides in the forest floor. In: Tree growth and forest soils, Proc. 3rd North Amer. Forest Soils Conf. C.T. Youngberg and C.B. Davey (eds.). Oregon State Univ. Press, Corvallis. p. 397-411.

Norris, L.A., M.L. Montgomery, and E.R. Johnson. 1977. The persistence of 2,4,5-T in a Pacific Northwest forest. Weed Sci. 25:417-422.

Plumb, T.R., L.A. Norris, and M.L. Montgomery. 1977. Persistence of 2,4-D and 2,4,5-T in chaparral soil and vegetation. Bull. Environ. Contam. Toxicol. 17:1-8.

Trichell, D.W., H.G. Morton, and M.G. Merkle. 1968. Loss of herbicides in runoff water. Weed Sci. 16:447-449.

Woodward, D.F. 1979. Assessing the hazard of picloram to cutthroat trout. J. Range Manage. 32:230-232. 